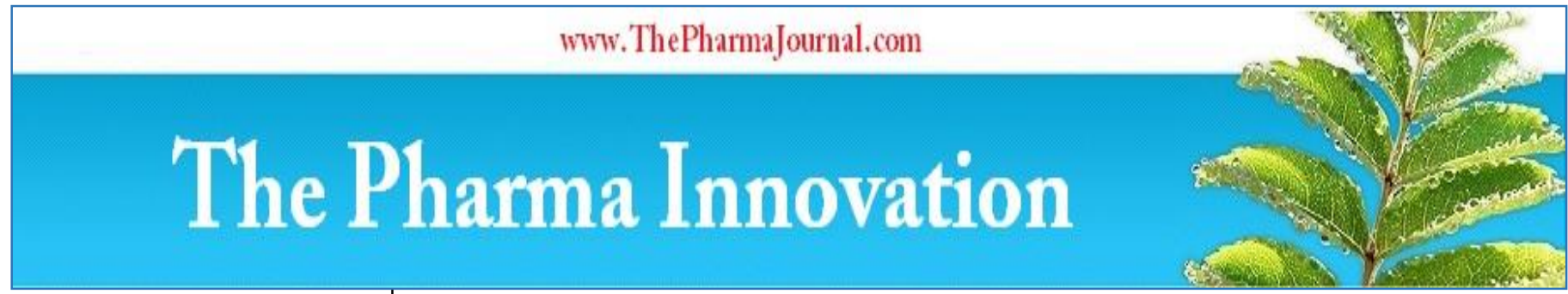

ISSN (E): 2277 - 7695

ISSN (P): 2349-8242

NAAS Rating: $\mathbf{5 . 0 3}$

TPI 2021; 10(2): 639-642

(C) $2021 \mathrm{TPI}$

www.thepharmajournal.com

Received: 14-12-2020

Accepted: 20-01-2021

Joyjit Das

College of Agriculture,

Lembucherra, Tripura, India

\section{Kalyan Pathak}

Assam Agricultural University,

Jorhat, Assam, India

\section{Santanu Das}

ICAR-KVK, Hailakandi, Assam, India

\section{JK Dey}

Department of Agronomy, Institute of Agriculture, VisvaBharati, Sriniketan, West Bengal, India

\section{Ashim Debnath}

Acharya Narendra Deva

University of Agriculture and

Technology, Kumarganj,

Ayodhya, Uttar Pradesh, India

\section{Response of late sown rapeseed varieties for physiological traits under different levels of irrigation}

\author{
Joyjit Das, Kalyan Pathak, Santanu Das, JK Dey and Ashim Debnath
}

DOI: $\underline{\text { htps://doi.org/10.22271/tpi.2021.v10.i2i.5750 }}$

Abstract

A field experiment was conducted at the Instructional-cum-Research (ICR) farm of Assam Agricultural University, Jorhat in 2013-14. The experiment was laid down in Factorial Randomized Block Design with three replications. The treatments consisted of four irrigation levels viz., one irrigation at flowering stage, two irrigations at flowering and siliqua formation stages, three irrigations at $20 \mathrm{DAS}$, flowering and siliqua formation stages and rainfed (no irrigation) with four varieties viz., M27, TS 38, TS 46 and TS 67. The results of the experiment revealed that three irrigations at 20 DAS, flowering and siliqua formation stages performed better than those with one irrigation at flowering and rainfed crop in response to physiological traits and biological yield. The variety TS 67 being at par with TS 38 recorded significantly higher growth traits and ultimately yield than those of M 27 and TS 46 .

Keywords: Crop growth rate, relative growth rate, leaf area index, biological yield and DAS days after sowing

\section{Introduction}

Oil seed receives greater attention in our country next to cereals. The oil of rapeseed and mustard is utilized for human consumption, industrial uses, condiments and spices. Rapeseed (Brassica campestris var. toria) is the second most important oilseed crop in India next to groundnut. Rajasthan and Uttar Pradesh are the major producing states in the country.

The productivity of the crop in India is low as compared to other countries (Rai et al., 2016) ${ }^{[8]}$. One of the primary reasons for low productivity is the unavailability of adequate irrigation during active growing period especially pod formation and pre flowering stages. The effect of water stress on crop is a function of genotype, intensity and duration of stress, weather conditions and developmental stages of rapeseed. In response to the water stress, plant faces physiological changes including loss of cell turger, closing of stomata, reduced cell enlargement and leaf surface area. All these abnormalities ultimately decrease photosynthesis and respiration which attributes overall reduction of crop production (Din et al., 2011) ${ }^{[4]}$. Irrigation levels also significantly affect the growth and yield of rapeseed (Roy et al., 2017) ${ }^{[9]}$. Rapeseed is usually sown from mid October to Mid November. But for adoption of multiple cropping systems, particularly after transplanting of winter rice, sowing time usually extend beyond the mid November. Growth and biological yield are functions of large number of metabolic processes which are affected by environmental and genetic factors. Genetic factor may be manipulated through the sowing of suitable cultivar capable of giving potential yield in late sowing condition. Moreover, delay in sowing would adversely influence the crop performance due to depletion of soil moisture. Therefore, it is necessary to save the crop from moisture stress condition either by growing drought tolerant varieties or by supplying irrigation water in order to obtain a good yield. After considering the above fact the aim of the present experiment was to evaluate the response of late sown rapeseed varieties for physiological traits under different levels of irrigation.

\section{Materials and Methods}

The experiment was undertaken in ICR farm of Assam Agricultural University, Jorhat, Assam in 2013-14. The surface soil $(0-15 \mathrm{~cm})$ of the experimental field was sandy loam in texture (sand, silt and clay content of 65, 22 and 13\%, respectively), moderately acidic in reaction ( $\mathrm{pH}$ $5.2)$, medium in available nitrogen $(298.3 \mathrm{~kg} / \mathrm{ha})$ and available phosphorus $(30.9 \mathrm{~kg} / \mathrm{ha})$ and low in available potassium $(91.5 \mathrm{~kg} / \mathrm{ha})$ with the soil field capacity, permanent wilting point
Corresponding Author: Joyjit Das

College of Agriculture,

Lembucherra, Tripura, India 
and hydraulic conductivity of $24.48 \% \mathrm{w} / \mathrm{w}, 11.21 \% \mathrm{w} / \mathrm{w}$ and $0.37 \mathrm{~cm} / \mathrm{hr}$, respectively. During the crop season $40.9 \mathrm{~mm}$ rainfall was received. The mean weekly maximum and minimum temperature ranged from $21.8{ }^{\circ} \mathrm{C}$ to $27.7{ }^{\circ} \mathrm{C}$ and $8.3^{\circ} \mathrm{C}$ to $13.7^{\circ} \mathrm{C}$, respectively. The mean weekly bright sun shine hours per day varied from 3.53 to 7.73 (hrs/day). The experiment was laid out in Factorial Randomized Block Design with three replications consisting of four irrigation levels viz. Irrigation at flowering stage $\left(\mathrm{I}_{1}\right)$, Irrigation at flowering and siliqua formation stages $\left(\mathrm{I}_{2}\right)$, Irrigation at 20 days after sowing (DAS), flowering and siliqua formation stages $\left(\mathrm{I}_{3}\right)$ and rainfed $\left(\mathrm{I}_{4}\right)$ with four varieties viz. M $27\left(\mathrm{~V}_{1}\right)$, TS-38 $\left(\mathrm{V}_{2}\right)$, TS- $46\left(\mathrm{~V}_{3}\right)$ and TS-67 $\left(\mathrm{V}_{4}\right)$. Irrigation to the crop was applied as per respective treatment. The amount of irrigation water was measured as follows:

$\mathrm{q}=\mathrm{a} \times \mathrm{d}$. where, $\mathrm{q}=$ quantity of water needed $\left(\mathrm{m}^{3}\right), \mathrm{a}=$ area to be irrigated $\left(12 \mathrm{~m}^{2}\right), \mathrm{d}=$ depth of water $(6 \mathrm{~cm})$.The sowing was done manually by placing the seeds in the furrows of 4 to $5 \mathrm{~cm}$ depth opened at $30 \mathrm{~cm}$ apart with seed rate @ $10 \mathrm{~kg} / \mathrm{ha}$ and plant to plant spacing was maintaining at 8 to $10 \mathrm{~cm}$. Five representative sample plants were selected randomly from individual plot and respective physiological traits of those tagged plants were measured accordingly.

The Crop growth rate represents dry weight gained by a unit area of crop in a given time. It was calculated using formula of Watson (1952) ${ }^{[13]}$ and expressed as $\mathrm{mg} / \mathrm{m}^{2} /$ day.

$$
\mathrm{CGR}=\frac{\mathrm{W}_{2}-\mathrm{W}_{1}}{\left(\mathrm{t}_{2}-\mathrm{t}_{1}\right) \mathrm{S}}
$$

The relative growth rate of crops at time instant $(\mathrm{T})$ is defined as the increase of plant material per unit of crop growth weight per unit time. It is expressed in $\mathrm{mg} / \mathrm{g} / \mathrm{day}$ (Watson, 1952) ${ }^{[13]}$.

$$
\mathrm{RGR}=\frac{\log _{\mathrm{e}} \mathrm{W}_{2}-\log _{\mathrm{e}} \mathrm{W}_{1}}{\left(\mathrm{t}_{2}-\mathrm{t}_{1}\right) \mathrm{S}}
$$

Where, $W_{1}$ and $W_{2}$ are plant dry weight at time $t_{1}$ and $t_{2}$, respectively, $\mathrm{S}$ is land area over which dry matter was recorded.

The leaf area index was calculated by dividing the leaf area per plant by land area occupied by the plant.

$$
\text { LAI }=\frac{\text { Leaf area/plant }\left(\mathrm{cm}^{2}\right)}{\text { Land area/plant }\left(\mathrm{cm}^{2}\right)}
$$

Two border rows on either side of the plot and $50 \mathrm{~cm}$ row length from both the ends of the rows were discarded. The plants from the net plot were pulled out by hand, tied into bundles separately for individual plot and were carried to thrashing floor. After 4 days of drying threshing was done by trampling with foot for individual plots. Then the Biological yield were measured in $\mathrm{kg} / \mathrm{plot}$ and convert to $\mathrm{q} / \mathrm{ha}$.

The data were analyzed statistically using standard procedure (Gomez and Gomez, 1984) ${ }^{[5]}$. Fisher's least significant difference was used to test the significance of differences at five percent probability level.

\section{Result and Discussion \\ Crop Growth Rate (CGR)}

Growth in terms of crop growth rate was not significantly influenced at 20 DAS under all the irrigation levels. However, after $40 \mathrm{DAS}$, irrigation at $20 \mathrm{DAS}$, flowering and siliqua formation $\left(\mathrm{I}_{3}\right)$ recorded the highest CGR which was followed by irrigation at flowering and siliqua formation $\left(\mathrm{I}_{2}\right)$ and irrigation at flowering $\left(\mathrm{I}_{1}\right)$. Variety TS $67\left(\mathrm{~V}_{4}\right)$ recorded markedly higher values for CGR at all the stages of growth. It was closely followed by variety TS $38\left(\mathrm{~V}_{2}\right)$ (Figure: 1$)$.

The better growth under these treatments $\left(I_{2}\right.$ and $\left.I_{3}\right)$ might be attributed to adequate soil moisture availability of rapeseed crop had in comparison with less or no irrigations. Further, it is understood that to increased photosynthetic surface and biomass accumulation by the crop under irrigated condition. Ansar (2013) ${ }^{[2]}$ and Singh et al. (2014) ${ }^{[11]}$ also observed improvement in overall growth of rapeseed with irrigation.

\section{Relative growth rate (RGR)}

Irrigation at $20 \mathrm{DAS}$, flowering and siliqua formation $\left(\mathrm{I}_{3}\right)$ recorded the highest RGR at all the crop growth stages. It was followed by irrigation at flowering and siliqua formation $\left(\mathrm{I}_{2}\right)$ and irrigation at flowering $\left(\mathrm{I}_{1}\right)$. Variety TS $67\left(\mathrm{~V}_{4}\right)$ recorded the highest value of RGR at all the stages of growth followed by variety $\mathrm{TS} 38\left(\mathrm{~V}_{2}\right)$ (figure: 2$)$.

An optimum moisture regime is very important for the balanced metabolic activities of the plants, which in turn, results in increased growth of the plants. In the present study, successive increase in irrigation levels had significant positive effect on relative growth rate. Which might be attributed to plant growth viz. cell division and elongation required a comparatively higher moisture supply from the soil. Piri et al. (2011) ${ }^{[7]}$ and Sonowal (2012) ${ }^{[12]}$ also observed enhancement in relative growth of rapeseed with balanced irrigation scheduling.

\section{Leaf area index (LAI)}

The effect of different irrigation levels on LAI was not significantly enhanced at 20 DAS. However, significant effect was observed at 40 and 60 DAS. The highest value was observed under irrigation at $20 \mathrm{DAS}$, flowering and siliqua formation $\left(\mathrm{I}_{3}\right)$ at $40 \mathrm{DAS}$. However, at $60 \mathrm{DAS}$, the treatment $\left(\mathrm{I}_{3}\right)$ was at par with irrigation at flowering and siliqua formation $\left(\mathrm{I}_{2}\right)$ and irrigation at flowering $\left(\mathrm{I}_{1}\right)$. At 40 DAS, the effect of varieties was statistically significant in respect of LAI. The maximum LAI was observed in variety TS $67\left(\mathrm{~V}_{4}\right)$ which was significantly higher than TS $38\left(\mathrm{~V}_{2}\right)$, M $27\left(\mathrm{~V}_{1}\right)$ and TS $38\left(\mathrm{~V}_{3}\right)$. (Table: 1) This might be attributed to increased photosynthetic amplitude and higher photosynthate accumulation. Similar results of all growth parameters were reported by Sharma (2009) ${ }^{[10]}$ and Ardestani et al. (2011) ${ }^{[3]}$. Katuwal et al. (2018) ${ }^{[6]}$ also found that irrigation at flowering stage increases the LAI.

\section{Seed yield and Stover yield}

A well nourished crop cultivar optimally supplied with water assimilates greater dry matter and translocate larger proportion at harvest. In the present study, application with two irrigations at flowering and siliqua formation stages $\left(\mathrm{I}_{2}\right)$ and application with three irrigations at 20 DAS, flowering and siliqua formation stages $\left(\mathrm{I}_{3}\right)$ produced higher values of yield attributes. Thus these two treatment applied to rapeseed produced the comparatively higher seed and stover yield than as compared to other treatments. Two irrigations at flowering and siliqua formation stages $\left(\mathrm{I}_{2}\right)$ produced 6.42 and $1.45 \%$ higher and 56.77 and $47.85 \%$ higher seed and stover yield than sole application of irrigation only at flowering $\left(\mathrm{I}_{1}\right)$ and 
rainfed crop $\left(\mathrm{I}_{4}\right)$ respectively. Corresponding increases with application of water with three irrigations i.e. at 20 DAS, flowering and siliquae formation stage $\left(\mathrm{I}_{3}\right)$ were recorded by 12.04 and $11.79 \%$ and 65.05 and $62.92 \%$ over sole application of irrigation only at flowering $\left(\mathrm{I}_{1}\right)$ and rainfed crop ( $\left.\mathrm{I}_{4}\right)$ respectively. Among the varietal evaluation maximum seed and stover yield was recorded with variety TS 67 (Table: 1). Higher yield due to application of irrigations contributed various yield components that influenced the yield accordingly. Irrigation had significant effects on growth characters as well as yield of rapeseed was well documented by Alamin et al. (2019) ${ }^{[1]}$.
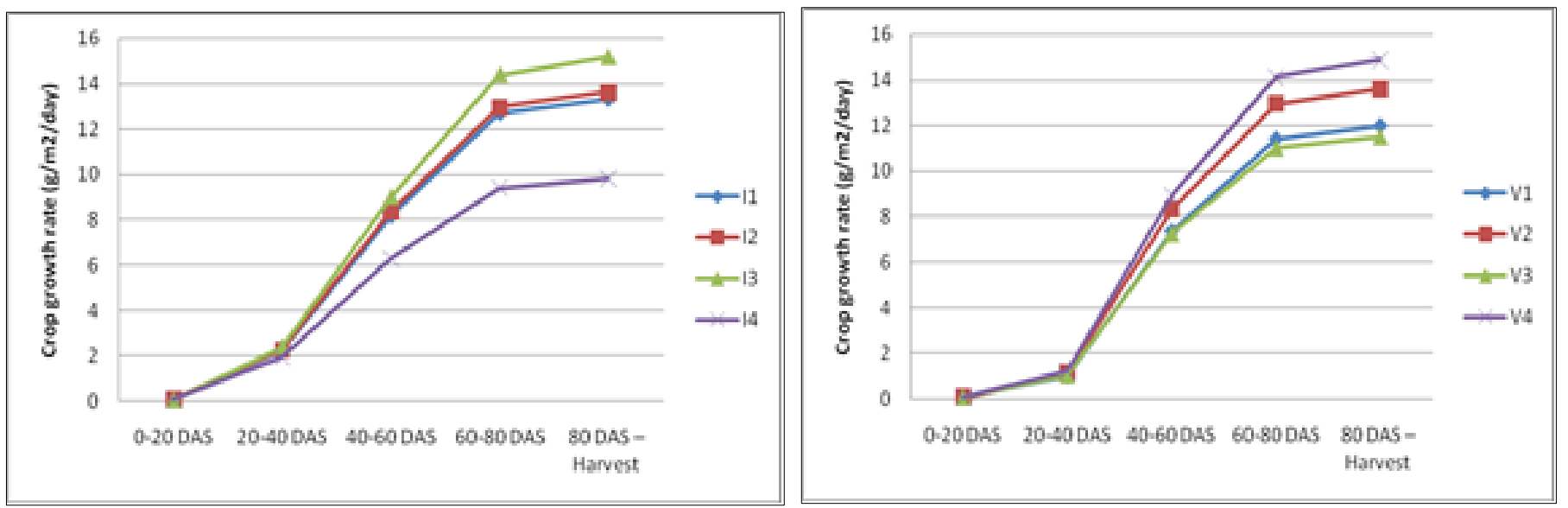

Fig 1: Effect of Irrigation and varieties on CGR (g/m²/day)
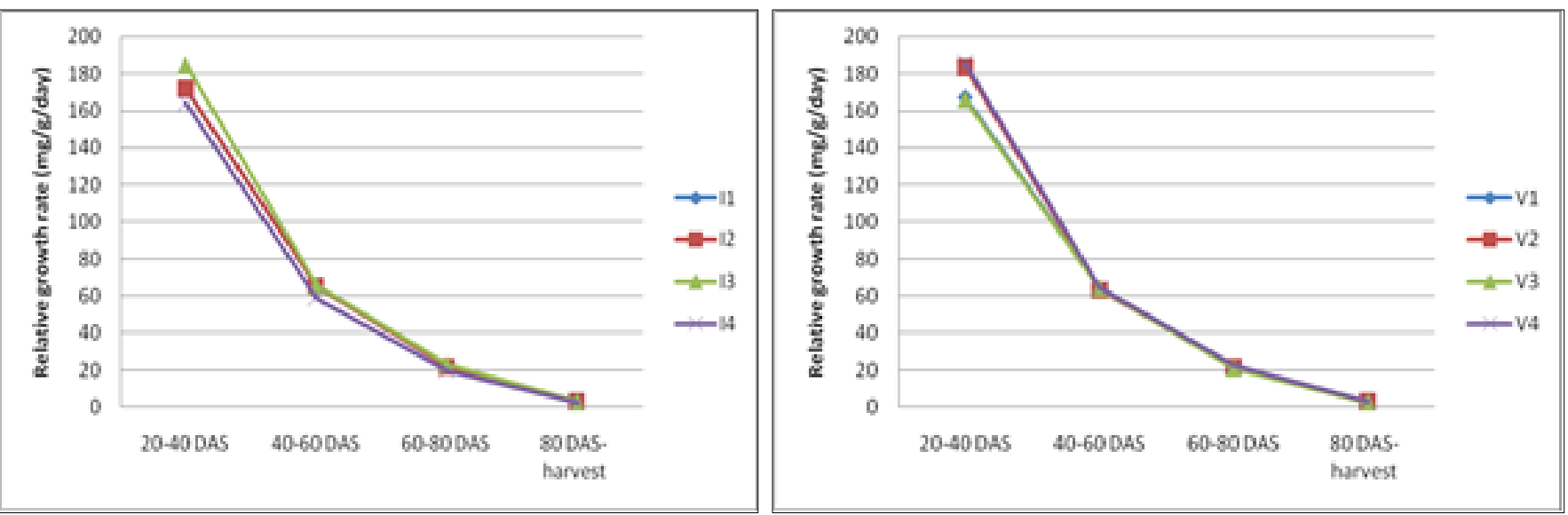

Fig 2: Effect of Irrigation and varieties on RGR (mg/g/day)

Table 1: Effect of different irrigation levels and varieties on Leaf area index and yield

\begin{tabular}{|c|c|c|c|c|c|}
\hline \multirow[t]{2}{*}{ Treatment } & \multicolumn{3}{|c|}{ Leaf Area Index } & \multicolumn{2}{|c|}{ Biological yield (q/ha) } \\
\hline & 20 DAS & 40 DAS & 60 DAS & Seed & Stover \\
\hline \multicolumn{6}{|c|}{ Irrigation level (I) } \\
\hline $\mathrm{I}_{1}$ : Irrigation at flowering & 0.07 & 1.73 & 0.89 & 13.7 & 25.43 \\
\hline $\mathrm{I}_{2}$ : Irrigation at flowering and siliqua formation & 0.06 & 1.75 & 0.91 & 14.58 & 25.8 \\
\hline $\mathrm{I}_{3}$ : Irrigation at $20 \mathrm{DAS}$, flowering and siliqua formation & 0.06 & 1.96 & 1.02 & 15.35 & 28.43 \\
\hline $\mathrm{I}_{4}:$ Rainfed & 0.07 & 1.19 & 0.72 & 9.3 & 17.45 \\
\hline S.Em+ & 0.01 & 0.05 & 0.05 & 0.28 & 0.85 \\
\hline $\mathrm{CD}(\mathrm{P}=0.05)$ & NS & 0.14 & 0.14 & 0.8 & 2.47 \\
\hline \multicolumn{6}{|c|}{ Variety $(\mathbf{V})$} \\
\hline $\mathrm{V}_{1}: \mathrm{M} 27$ & 0.07 & 1.56 & 0.88 & 13.09 & 23.93 \\
\hline $\mathrm{V}_{2}: \mathrm{TS} 38$ & 0.07 & 1.73 & 0.86 & 13.26 & 24.57 \\
\hline $\mathrm{V}_{3}: \mathrm{TS} 46$ & 0.06 & 1.54 & 0.88 & 12.66 & 22.1 \\
\hline $\mathrm{V}_{4}:$ TS 67 & 0.06 & 1.77 & 0.89 & 13.92 & 26.51 \\
\hline S.Em+ & 0.01 & 0.05 & 0.05 & 0.28 & 0.85 \\
\hline $\mathrm{CD}(\mathrm{P}=0.05)$ & NS & 0.14 & NS & 0.8 & 2.47 \\
\hline
\end{tabular}

\section{Conclusion}

Based on field experimental studies, it may be concluded that two irrigations should be applied at flowering and siliqua formation stages for achieving higher growth and yield. The variety TS 67 or TS 38 may be best suited for that region on account of growth behavior.

\section{Reference}

1. Alamin Md. RM, Md. Fatima S, Nahar K, Ahamed KU. Effect of Sowing Time and Irrigation Frequency on Growth and Yield of Mustard (Brassica napus L.). International Journal of Advances in Agriculture Sciences 2019;4(8):01-11. 
2. Ansar Z, Kamali M, Baradaran M, Abadi F. Effect of Irrigation and Nitrogen on Two Canola Cultivars. International Journal of Agronomy and Plant Production 2013;4(7):1409-1418.

3. Ardestani HG, Rad AHS, Zandi P. Effect of drought stress on some agronomic traits of two rapeseed varieties grown under different potassium rates. Australian Journal Basic Applied Science 2011;5(12):2875-2882.

4. Din J, Khan SU, Ali I, Gurmani AR. Physiological and agronomic response of canola varieties to drought stress. Journal of Animal and Plant Sciences 2011;21(1):78-82.

5. Gomez KA, Gomez AA. Statistical producer for agricultural research, $2^{\text {nd }}$ Edn.John wiley and sons, New York 1984.

6. Katuwal KB, Sangamesh V, Singh S, Cho Y, Begna S, Umesh MR. Growth-Stage-Based Irrigation Management on Biomass, Yield, and Yield Attributes of Spring Canola in the Southern Great Plains. Crop Science 2018;58:1-10

7. Piri I, Nik MM, Tavassoli A, Rastegripour F. Effect of irrigation intervals and sulphur fertilizer on growth analysis and yield of Brassica juncea. African Journal of biotechnology 2011;10(55):11459-11467.

8. Rai SK, Charak D, Bharat R. Scenario of oilseed crops across the globe. Plant Archives 2016;16(1):125-132

9. Roy KC, Rahman MM, Rahman K, Miah M, Hossain A, Zaman M. Effects of irrigation and sulphur: application on growth, yield and oil content of rapeseed (Brassica napus). Eco-friendly Agricultural Journal 2017; 10(03):30-34.

10. Sharma R. Effect of seed rate and fertilizer levels on late sown rapeseed (toria).M.Sc. thesis, AAU Jorhat 2009.

11. Singh AK, Singh RR, Singh AK, Singh PK. Influence of dates of sowing and irrigation scheduling on growth and yield of mustard (Brassica juncea L). International Journal of Farm Sciences 2014;4(2):80-85.

12. Sonowal D. Performance of toria under different levels of irrigation and potassium. M.Sc. (Agri.) Thesis submitted to the Department of Agronomy, Assam Agricultural University, Jorhat 2012.

13. Watson DJ. The physiological basis of varieties in yield. Advances in Agronomy 1952;4:101-145. 